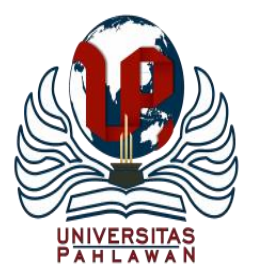

Jurnal Basicedu Volume 5 Nomor 1 Tahun 2021 Halaman 406-417

JURNAL BASICEDU

Research \& Learning in Elementary Education

https://jbasic.org/index.php/basicedu

\title{
Penerapan Model Kooperatif Tipe Learnig Start With A Question untuk Meningkatkan Kemampuan Membaca di Sekolah Dasar
}

\author{
Yanti Yandri Kusuma \\ Universitas Pahlawan Tuanku Tambusai, Indonesia \\ E-mail : Zizilia.yanti@gmail.com
}

\begin{abstract}
Abstrak
Penelitian ini bertujuan dapat meningkat kemampuan membaca selalu berhemat energi pada tema 2 di kelas IV Sekolah Dasar PT Tunggal Yunus melalui penerapan model kooperatif tipe learnig start with a question. Penelitian ini dilatar belakangi oleh rendahnya hasil kemampuan membaca selalu berhemat energi pada tema 2 yang tidak mencapai nilai KKM yang ditetapkan sekolah yaitu 76. Penelitian ini merupakan penelitian tindakan kelas. Subjek penelitian ini adalah siswa kelas IV tahun ajaran 2019-2020 dengan jumlah siswa sebanyak 25 orang. Objek dalam penelitian ini adalah model pembelajaran kooperatif tipe learning start with a question, dan kemampuan membaca selalu berhemat energi pada tema 2. Penelitian ini terdiri dari empat tahapan tiap siklus yaitu: perencanaa, pelaksanaan, pengamatan, dan refleksi. Penelitian ini dilakukan sebanyak 2 siklus yang masing-masing siklus terdiri dari dua kali pertemuan. Pengumpulan data dalam penelitian ini menggunakan dokumentasi dan tes. Berdasarkan hasil analisis data dapat diketahui bahwa terjadinya peningkatan kemampuan membaca selalu berhemat energi pada tema 2. Sebelum tindakan ketuntasan hasil kemampuan membaca selalu berhemat energi pada tema 2 siswa hanya mencapai $27 \%$, lalu pada siklus I pertemuan I meningkat menjadi $40 \%$, siklus I pertemuan II meningkat menjadi 55\% dan pada siklus II pertemuan I meningkat menjadi $80 \%$ kemudian siklus II pertemuan II meningkat lagi menjadi 95\%. Dengan demikian dapat disimpulkan bahwa penerapan model kooperatif tipe learnig start with a question dapat meningkatkan kemampuan membaca selalu berhemat energi pada tema 2 di Kelas IV Siswa Sekolah Dasar.
\end{abstract}

Kata kunci: model learnig start with a question, kemampuan membaca selalu berhemat energi

\section{Abstract}

This study aims to improve reading skills and always save energy on theme 2 in grade IV of PT Tunggal Yunus Elementary School through the application of the Think Talk Write type cooperative model. This research is motivated by the low results of the ability to read always save energy on theme 2 which does not reach the KKM value set by the school, which is 76. This research is a classroom action research. The subject of this research is fourth grade students of the 2019-2020 academic year with a total of 25 students. The object of this research is the cooperative learning model of the Think Talk Write type and the ability to read is always energy efficient in theme 2. This research consists of four stages in each cycle, namely: planning, implementing, observing, and reflecting. This research was conducted in 2 cycles, each cycle consisting of two meetings. Data collection in this study used documentation and tests. Based on the results of data analysis, it can be seen that an increase in reading skills always saves energy on theme 2. Before completing the action results of the ability reading always saves energy on theme 2 students only reaches 27\%, then in cycle I meeting I increases to 40\%, cycle I meeting II increases to 55\% and in cycle II meeting I increases to $80 \%$ then cycle II meeting II increases again to become 95\%. Thus it can be concluded that the application of the Think Talk Write Type Cooperative Model can improve reading skills always save energy on theme 2 in Class IV Elementary School Students.

Keywords: learnig start with a question Model, the ability to read always saves energy

Copyright (c) 2021 Yanti Yandri Kusuma

$\triangle$ Corresponding author

Address : Universitas Pahlawan Tuanku Tambusai

Email : Zizilia.yanti@gmail.com

Phone : 085272188477

ISSN 2580-3735 (Media Cetak)

ISSN 2580-1147 (Media Online)

DOI: https://doi.org/10.31004/basicedu.v5i1.723 
407 Penerapan Model Kooperatif Tipe Learnig Start With A Question untuk Meningkatkan Kemampuan Membaca di Sekolah Dasar - Yanti Yandri Kusuma

DOI: https://doi.org/10.31004/basicedu.v5i1.723

\section{PENDAHULUAN}

Pendidikan merupakan bimbingan atau pertolongan yang diberikan oleh orang dewasa kepada perkembangan anak untuk mencapai kedewasaanya dengan tujuan agar anak cukup cakap melaksanakan tugas hidupnya sendiri tidak dengan bantuan orang lain".

Menurut H. Fuad Ihsan (2005) menjelaskan bahwa dalam pengertian yang sederhana dan umum makna pendidikan sebagai "usaha manusia untuk menumbuhkan dan mengembangkan potensi-potensi pembawaan baik jasmani maupun rohani sesuai dengan nilai-nilai yang ada didalam masyarakat dan kebudayaan". Usaha-usaha yang dilakukan untuk menanamkan nilai-nilai dan norma-norma tersebut serta mewariskan kepada generasi berikutnya untuk dikembangkan dalam hidup dan kehidupan yang terjadi dalam suatu proses pendidikan sebagai usaha manusia untuk melestarikan hidupnya

Undang-Undang Sistem Pendidikan Nasional No. 20 Tahun 2003, disebutkan bahwa pendidikan adalah usaha sadar dan berencana untuk mewujudkan suasana belajar agar peserta didik aktif mengembangkan potensi dirinya terhadap kekuatan spiritual keagamaan, pengendalian, kepribadian, kecerdasan, akhlak mulia serta keterampilan yang diperlukan dirinya, masyarakat, bangsa dan negara.

Jhon Dewey (2003) menjelaskan bahwa "pendidikan adalah proses pembentukan kecakapan-kecakapan fundamental secara intelektual dan emosional kearah alam dan sesama manusia”. Sedangkan menurut J.J.Rousseau (2003) menjelaskan bahwa "pendidikan merupakan memberikan kita pembekalan yang tidak ada pada masa kanak-kanak, akan tetapi kita membutuhkanya pada masa dewasa".

Dilain pihak Oemar Hamalik (2001) menjelaskan bahwa "pendidikan adalah suatu proses dalam rangka mempengaruhi siswa agar dapat menyesuaikan diri sebaik mungkin terhadap lingkungan dan dengan demikian akan menimbulkan perubahan dalam dirinya yang memungkinkannya untuk berfungsi secara kuat dalam kehidupan masyarakat". Bahasa Indonesia menurut I.G.N Oka dan Suparno adalah sistem simbol suara lisan yang arbitrer yang dipakai oleh sekelompok orang (masyarakat) sebagai perangkat komunikasi. Permendikbud nomor 23 tahun 2006 menyatakan bahwa tujuan pembelajaran bahasa membentuk manusia Indonesia yang kebangsaan cinta tanah air. Adapun standar kompetensi lulusan mata pelajaran Bahasa Indonesia menurut Permendiknas nomor 23 tahun 2006 meliputi aspek mendengarkan, berbicara, membaca, dan menulis.

Pentingnya berbahasa Indonesia ditujukan agar para siswa lebih menghargai Bahasa Indonesia, serta mempunyai kemampuan yang baik dan benar sesuai dengan etika dan kesopanan. Bahasa yang baik berarti berbahasa sesuai dengan situasi dan kondisi yang ada, sedangkan berbahasa yang benar berarti berbahasa sesuai dengan kaidah bahasa. Oleh karena itu para siswa diharapkan bisa menggunakan bahasa Indonesia dengan tepat.

Tujuan utama dari pembelajaran suatu bahasa yakni peran pentingnya di dalam 
408 Penerapan Model Kooperatif Tipe Learnig Start With A Question untuk Meningkatkan Kemampuan Membaca di Sekolah Dasar - Yanti Yandri Kusuma

DOI: https://doi.org/10.31004/basicedu.v5i1.723

perkembangan intelektual dan emosional siswa serta sebagai penunjang keberhasilan dalam mempelajari pelajaran yang lainnya. Adapun dalam pembelajaran bahasa di bangku sekolah sebagai pembantu para siswa untuk mengenal dirinya sendiri, budayanya, budaya orang lain, belajar untuk menyampaikan gagasan, serta mampu menggunakan kemampuan imajinatif dan analitis yang terdapat pada diri masing-masing. Di samping itu pembelajaran bahasa juga dapat meningkatkan kemampuan kita untuk berkomunikasi dengan orang lain dan berbagi pengalaman untuk saling mempelajari satu sama lain.

Mempelajari Bahasa Indonesia juga dapat membuat kita lebih terampil dalam berbahasa Indonesia, seperti yang sering kita lakukan di sekolah yaitu menyimak, berbicara, menulis dan mendengar. Selain itu para siswa juga diharapkan mampu berekspresi dan lebih menikmati sastra, seperti puisi, pantun, gurindam, dan lain-lain.

Dengan mempelajari Bahasa Indonesia para siswa diharapkan mampu membaca dan memperluas wawasan mereka serta bisa memperhalus budi pekerti dan juga bisa semakin menghargai Bahasa Indonesia dan bangga terhadap bahasa pemersatu bangsa tersebut.

Berdasarkan tujuan tersebut dapat disimpulkan bahwa pembelajaran bahasa di sekolah dasar diharapkan peserta didik mendapat bekal yang matang untuk mengembangkan dirinya dalam pendidikan berikutnya dan hidup bermasyarakat. Dalam bidang pengetahuan peserta didik memiliki pemahaman dasar-dasar kebahasaan terutama bahasa baku serta mempunyai sikap positif terhadap Bahasa Indonesia.

Salah satu aspek dalam pembelajaran Bahasa Indonesia yang harus dikuasai peserta didik adalah menulis, "Menulis merupakan salah satu dari empat keterampilan berbahasa (mendengarkan, berbicara, membaca, dan menulis. Menulis merupakan suatu proses bagaimana mengkomunikasikan ide kepada orang lain dengan baik, sehingga orang lain dapat memahami apa yang disampaikan melalui tulisan"(Tarmizi, 2013:12).

Keterampilan pada pembelajaran Bahasa Indonesia siswa diharapkan mampu menggunakan berbagai jenis wacana tulis untuk menggungkapkan pikiran, perasaan, dan informasi dalam bentuk teks. Kegiatan menulis tersebut dapat digolongkan dalam menulis kreatif atau menulis faktual. Salah satu kegiatan menulis kreatif adalah menulis Membaca Selalu Hemat Energi pada Tema 2 Kelas IV. Alasan memilih jenis Membaca Selalu Hemat Energi pada Tema 2 Kelas IV ini karena sesuai dalam silabus pembelajaran kelas IV yaitu Standar Kompetensi: macam-macam sumber energi, dan informasi dalam membaca selalu hemat energi pada tema 2 kelas IV SD.

Berdasarkan observasi yang dilakukan oleh peneliti pada tanggal 11 Nopember 2019 di SD PT. Tunggal Yunus Pertapahan Kabupaten Kampar, berdasarkan data nilai pada mata pelajaran Bahasa Indonesia materi keterampilan menulis karangan narasi yang diperoleh peneliti dari guru kelas IV 
409 Penerapan Model Kooperatif Tipe Learnig Start With A Question untuk Meningkatkan Kemampuan Membaca di Sekolah Dasar - Yanti Yandri Kusuma

DOI: https://doi.org/10.31004/basicedu.v5i1.723

SD PT. Tunggal Yunus Pertapahan pada semester genap Tahun Ajaran 2018/2019 mengalami permasalahan. Dari 25 siswa, yang tuntas hanya 10 siswa $(35 \%)$ dan tidak tuntas berjumlah 15 siswa $(65 \%)$.

Data tersebut memperlihatkan masih banyak siswa yang belum mencapai Kriteria Ketuntasan Minimal (KKM). terdapat beberapa masalah yang menyebabkan rendahnya Kemampuan Selalu Hemat Energi di tema 2 kelas IV Sekolah Dasar yaitu keterbatasan mengeja, model pembelajaran membaca tidak berorientasi pada siswa, ketidakmampuan siswa dalam menentukan topik, ketidak mampuan siswa dalam membentuk judul, ketidakmampuan siswa dalam menentukan bentuk penulisan, kurangnya penggunaan diksi atau pilihan kata, ketidakmampuan siswa untuk membaca, ketidak mampuan guru membangkitkan keaktifan siswa, ketidakmampuan guru membimbing siswa saat siswa membaca selalu berhemat energi pada buku tema 2 di kelas IV Sekolah Dasar. Ketidakmampuan guru dalam menemukan dan menerapkan model pembelajaran yang tepat dalam mengajar materi membaca selalu hemat energi pada tema 2 di kelas IV Sekolah Dasar.

Berdasarkan permasalahan yang telah dipaparkan, maka perlu dilakukan perbaikan dalam proses pembelajaran. Salah satunya dengan menggunakan model yang sesuai dengan Membaca Selalu Hemat Energi pada tema 2 di kelas IV. Peneliti mencoba memberikan rekomendasi pada perbaikan proses pembelajaran khususnya pada materi membaca selalu hemat energi pada tema 2 dengan menggunakan model Learnig Start With a Question.

Berdasarkan latar belakang tersebut maka peneliti merekomendasikan penelitian dengan judul "Penerapan Model Learnig Start With a Question untuk Meningkatkan kemampuan membaca tema 2 pada siswa Sekolah Dasar"

Kemampuan membaca mempunyai kedudukan yang sangat penting, terlebih untuk siswa sekolah dasar karena membaca merupakan kemampuan awal yang harus dimiliki oleh setiap siswa agar dapat memahami apa yang dipelajarinya. Silabus pada tingkat sekolah dasar harus menekankan kepada kemampuan membaca. Hal tersebut dicantumkan dalam Peraturan Pemerintah Republik Indonesia Nomor 19 Tahun 2005 bab III pasal 6 ayat 6 yang menyatakan bahwa, "Kurikulum dan silabus SD/MI/SDLB/PAKET A atau bentuk lain yang sederajat menekankan pentingnya kemampuan dan kegemaran membaca, menulis, kecakapan berhitung, serta kemampuan berkomunikasi." Adapun rumusan masalah dalam penelitian ini yaitu bagaimanakah pelaksanaan metode pada siswa kelas IV dan bagaimanakah Penerapan Model Learnig Start With a Question Untuk Meningkatkan kemampuan membaca tema 2 pada siswa kelas IV Sekolah Dasar.

\section{METODE}

Penelitian ini menggunkan metode kualitatif yang berjenis Penelitian Tindakan Kelas (Class Action Research). Arikunto ( Iskandar, 2009:20) mengatakan bahwa, "Penelitian Tindakan Kelas merupakan suatu pencermatan terhadap kegiatan 
pembelajaran berupa sebuah tindakan, yang sengaja dimunculkan dan terjadi dalam sebuah kelas secarabersamaan". Selain itu, Iskandar (2009:21) juga menyatakan bahwa "Penelitian Tindakan Kelas adalah suatu kegiatan penelitian ilmiah yang dilakukan secara rasional, sistematis dan empiris reflektif terhadap berbagai tindakan yangdilakukan oleh guru atau dosen (tenaga pendidik), kolaborasi (tim peneliti) yangsekaligus sebagai peneliti, sejak disusunnya suatu perencanaan sampai penilaianterhadap tindakan nyata di dalam kelas yang berupa kegiatan belajar mengajar,untuk memperbaiki dan meningkatkan kondisi pembelajaran yang dilakukan".

Subjek penelitian adalah seluruh siswa kelas IV SD PT.Tunggal Yunus Pertapahan Kabupaten Kampar dengan jumlah siswa 25 orang, yang terdiri dari 10 orang siswa laki-laki dan 15 orang siswa perempuan. Penelitian tindakan kelas ini dilaksanakan dua siklus. Siklus pertama dilaksanakan dua kali pertemuan dan siklus kedua juga dua kali pertemuan. Alokasi waktu pada setiap pertemuan 70 menit. Pelaksanaan masingmasing siklus mengikuti tahap-tahap perencanaan, tindakan, observasi, dan refleksi.

Berhasil tidaknya penelitian dilakukan dapat diketahui dari data yang diperoleh. Terkait dengan itu, untuk memperoleh data dalam menjawab masalah penelitian dapat dilakukan dengan menggunakan instrumen penelitian yaitu sebuah alat bantu yang dipilih peneliti dalam kegiatan pengumpulan data, agar kegiatan tersebut berjalan dengan sistematis (Arikunto dalam Sarjana, 2010:43). Data penelitian yang digunakan dalam penelitian tindakan kelas ini berupa observasi dan tes sebagai metode utama untuk memperoleh data.

Instrumen penelitian adalah alat atau fasilitas yang digunakan peneliti dalam mengumpulkan data agar pekerjaannya lebih mudah dan hasilnya lebih baik, dalam arti lebih cermat, lengkap dan sistematis sehingga lebih mudah diolah. Agar penelitian ini dapat dilaksanakan dengan baik maka perlu dipersiapkan instrumen penelitian. Adapun instrumen penelitian yang perlu dipersiapkan sebagai berikut:

1. Instrumen Perencanaan Pembelajaran berfungsi untuk menilai perencanaan pembelajaran peneliti menggunakan lembar instrumen perencanaan pembelajaran yang akan dinilai oleh observer pada setiap pembelajaran siklus I dan siklus II.

2. Lembar Observasi berfungsi untuk menilai kegiatan yang dilakukan peneliti dalam melaksanakan penelitian, observer akan mengisi lembaran observasi yang mencatat kegiatan peneliti dari awal sampai akhir. Lembar observasi terbagi dua bagian yaitu lembar observasi aktivitas guru dan lembar observasi aktivitas siswa.

3. Rubrik penilaian karangan narasi berfungsi untuk mengetahui peningkatan kemampuan membaca selalu hemat energi pada tema 2 di kelas IV siswa telah mencapai KKM atau belum, peneliti menggunakan rubrik penilaian membaca pada Tema 2 yang dibuat oleh peneliti.

Teknik pengumpulan data merupakan langkah yang paling strategis dalam penelitian karena tujuan utama dari penelitian adalah untuk 
411 Penerapan Model Kooperatif Tipe Learnig Start With A Question untuk Meningkatkan Kemampuan Membaca di Sekolah Dasar - Yanti Yandri Kusuma

DOI: https://doi.org/10.31004/basicedu.v5i1.723

mendapatkan data. Adapun teknik pengumpulan data yang akan diambil sebagai berikut:

1. Teknik Dokumentasi yang digunakan dalam penelitian ini adalah menganalisis RPP. Hasil dari dokumentasi ini digunakan untuk mendeskripsikan perencanaan pelaksanaan pembelajaran dengan penerapan model learnig start with a question.

2. Teknik Observasi digunakan untuk mengumpulkan data tentang aktivitas guru dan siswa ketika proses pembelajaran berlangsung dengan menggunakan penerapan model learnig start with a question.

3. Teknik Tes digunakan untuk mengumpulkan data tentang $\mathrm{K}$. Tes menggunakan test formatif berupa Lembar Tugas Siswa (LTS) yang diberikan kepada siswa untuk menulis karangan narasi yang akan dilaksanakan pada akhir pembelajaran siklus I dan II.

Analisis data yang digunakan dalam penelitian ini adalah analisis kuantitatif dan analisis kualitatif. Analisis kuantitatif digunakan untuk menganalisis nilai rata-rata dan persentase skor hasil keterampilan menulis karangan narasi siswa. Sedangkan analisis kualitatif digunakan untuk menganalisis lembar observasi kegiatan siswa dan guru saat proses pembelajaran. Berikut penjelasannya:

\section{Analisis Kuantitatif}

a. Ketuntasan Belajar Individu

Adapun pedoman rubrik yang digunakan dalam penelitian kemampuan membaca selalu hemat energi pada tema 2 di kelas IV siswa SD PT. Tunggal Yunus. Peneliti membuat rubrik penilaian
Kemampuan membaca untuk menilai hasil kemampuan membaca siswa. Adapun aspek yang dinilai ada 3 yaitu :

1. pemahaman literal

2. interpretasi

3. membaca kritis

4. membaca kreatif

Siswa dikatakan tuntas apabila nilainya mencapai KKM atau lebih tinggi dari KKM yaitu 76. Untuk menentukan ketuntasan yang dicapai siswa peneliti menggunakan rumus yang digunakan yaitu:

$$
K B S I=\frac{\text { Skor yang diperoleh siswa }}{\text { Skor Maksimum }} \times 100
$$

Keterangan :

KBSI = Ketuntasan Belajar Siswa Secara Individu

b. Ketuntasan Klasikal

Jika ketuntasan klasikal siswa telah mencapai $80 \%$ dari seluruh siswa, maka secara klasikal telah tercapai dengan baik. (Wardhani, 2007:25).

$K K=\frac{\text { Jumlah Siswa yang tuntas }}{\text { Jumlah Seluruh siswa }} \times 100 \%$

Keterangan:

$\mathrm{KK}=$ Ketuntasan Klasikal

Adapun kriteria proses pembelajaran keterampilan menulis karangan narasi dapat dilihat pada tabel berikut: 
412 Penerapan Model Kooperatif Tipe Learnig Start With A Question untuk Meningkatkan Kemampuan Membaca di Sekolah Dasar - Yanti Yandri Kusuma

DOI: https://doi.org/10.31004/basicedu.v5i1.723

Tabel 1. Interval Kriteria Ketuntasan Klasikal

\begin{tabular}{|c|l|l|}
\hline No & \multicolumn{1}{|c|}{ Interval } & \multicolumn{1}{|c|}{ Kategori } \\
\hline 1 & $90-100 \%$ & Baik Sekali \\
\hline 2 & $80-89 \%$ & Baik \\
\hline 3 & $70-79 \%$ & Cukup \\
\hline 4 & $60-69 \%$ & Kurang \\
\hline 5 & $<59 \%$ & Sangat Kurang \\
\hline
\end{tabular}

Sumber: (Riduan \& Sunarto, 2012:20)

\section{HASIL DAN PEMBAHASAN}

Sebelum melakukan tindakan, peneliti melakukan observasi yaitu untuk mengetahui kemampuan siswa dalam Membaca Selalu Hemat Energi pada tema 2 di kelas IV Sekolah Dasar. Data dari observasi dan wawancara awal yang dilakukan dengan guru kelas IV PT. Tunggal Yunus Kabupaten kampar, bahwa hasil belajar siswa khususnya pada mata pelajaran Bahasa Indonesia terutama membaca selalu hemat energi pada tema 2 kelas IV Sekolah Dasar masih belum sesuai dengan yang diharapkan.

Berdasarkan data nilai Kemampuan Membaca Selalu Hemat Energi pada tema 2 kelas IV Sekolah Dasar yang diperoleh dari guru kelas IV Sekolah Dasar Pertapahan. Peneliti menganalisis data tersebut dengan $\mathrm{KKM} 76$, dari 25 siswa hanya 15 siswa (35\%) orang siswa yang mencapai KKM. Sedangkan siswa yang tidak mencapai KKM sebanyak 10 siswa (65\%).

\section{Deskripsi Hasil Tindakan Tiap Siklus}

Perbandingan kemampuan membaca selalu hemat energi pada tema 2 kelas IV Sekolah Dasar dengan menggunakan model Learnig Start With A Question kelas IV di SD PT.Tunggal Yunus pada siklus I dan siklus II terdapatnya peningkatan pada kemampuan membaca selalu hemat energi pada tema 2 kelas IV Sekolah Dasar dengan menggunakan model Learnig Start With A Question kelas IV SD PT.Tunggal Yunus.

Diketahui bahwa nilai rata-rata siswa pada siklus I pertemuan 1 sebesar 76 dengan kategori kurang (60\%-69\%) dan meningkat pada pertemuan 2 sebesar 83,95 dengan kategori cukup (70\%-79\%). Kemudian pada siklus II pertemuan 1 mengalami peningkatan menjadi 85,25 dengan kategori cukup (70\%-79\%). Lalu meningkat lagi pada pertemuan 2 menjadi 85,7 dengan kategori baik (80\%-89\%). Sedangkan presentase ketuntasan klasikal kemampuan membaca selalu hemat energi pada tema 2 kelas IV Sekolah Dasar pada siklus I pertemuan 1 sebesar 30\% dengan kategori kurang sekali $(<59 \%)$ dan pertemuan 2 meningkat menjadi $55 \%$ dengan kategori kurang sekali $(<59 \%)$.

Pada siklus II pertemuan 1 meningkat menjadi $80 \%$ dengan kategori cukup (70\%79\%).Kemudian meningkat lagi pada pertemuan 2 sebesar 95\% dengan kategori baik (80\%-89\%). Untuk mengetahui perkembangan Kemampuan.

Berdasarkan tabel 4.7 menunjukkan bahwa nilai rata-rata kelas dari data awal 73,6 meningkat pada siklus I pertemuan 1 sebesar 76. Kemudian meningkat lagi pada pertemuan 2 menjadi 85,5 Siklus II pertemuan 1 sebesar 78,25. Lalu meningkat pada pertemuan 2 menjadi 82,7. Begitu juga dengan ketuntasan secara klasikal dari data awal 35\% meningkat pada siklus I pertemuan 1 sebesar $40 \%$ dan pada pertemuan 2 menjadi $55 \%$. Pada siklus II pertemuan 1 sebesasr $80 \%$ dan di pertemuan 2 meningkat lagi menjadi $85 \%$. 
413 Penerapan Model Kooperatif Tipe Learnig Start With A Question untuk Meningkatkan Kemampuan Membaca di Sekolah Dasar - Yanti Yandri Kusuma

DOI: https://doi.org/10.31004/basicedu.v5i1.723

Berdasarkan dari hasil penelitian yang telah dilakukan, maka beberapa hal yang akan dibahas terkait penelitian ini adalah:

\section{Perencanaan Peningkatan Kemampuan} Membaca Selalu hemat Energi pada Tema 2 kelas IV Dengan Menggunakan Model Pembelajaran Kooperatif Learnig Start With

\section{A Question}

Pada perencanaan pelaksanaan siklus I dan siklus II dalam pembelajaran Bahasa Indonesia pada materi membaca pada siswa kelas IV SD PT.Tunggal Yunus, perencanaan pembelajaran perlu dibuat sebagaimana yang dikemukakan (Suyatno, 2009) setiap guru pada satuan pendidikan berkewajiban menyusun RPP secara lengkap agar pembelajaran berlangsung secara inspiratif, menyenangkan, menantang, memotivasi peserta didik untuk berpartisipasi aktif, serta memberikan kreativitas, dan kemandirian sesuai dengan bakat dan minat.

Sebelum melakukan tindakan, peneliti terlebih dahulu harus membuat perencanaan karena proses pembelajaran perlu direncanakan, seperti yang dikemukakan (Arikunto, 2015) seorang guru dapat melakukan perencanaan dalam membuat PTK seperti merancang skenario pembelajaran, dan menetapkan indikator pencapaian, serta menyusun instrumen penelitian. Adapun perencanaan yang disusun oleh peneliti dalam penelitian ini adalah, menyusun silabus, menyusun RPP berdasarkan tahapan pada model kooperatif learnig start with a question yaitu,mempersiapkan lembar observasi aktivitas guru, mempersiapkan lembar observasi aktivitas siswa, meminta guru kelas yaitu ibu Suryani,S.Pd untuk menjadi observer I mengamati aktivitas guru dan meminta kesediaan teman sejawat yaitu Deti Ardiati untuk menjadi observer II mengamati aktivitas siswa, serta mempersiapkan lembar tugas siswa.

Adapun komponen-komponen penting yang ada dalam rencana pembelajaran meliputi: identitas sekolah, standar kompetensi. kompetensi dasar, Indikator, tujuan pembelajaran, materi pokok, penerapan langkah-langkah model kooperatif learnig start with a question, sumber pembelajaran, dan penilaian. Berdasarkan dari penilaian yang dilakukan oleh observer I terhadap perencanaan yang dilakukan oleh peneliti pada siklus I adalah persiapan yang dilakukan oleh guru praktisi seperti kesesuaian antara indikator dengan standar kompetensi dan kompetensi dasar sudah sesuai, kemudian pemilihan materi ajar telah sesuai dengan tujuan pembelajaran, pemilihan materi ajar telah sesuai dengan karakteristik peserta didik, serta kesesuaian antara pemilihan materi ajar dengan alokasi waktu juga sudah sesuai.

Secara keseluruhan, penilaian dalam perencaan ini sudah lumayan baik meskipun masih perlu diperbaiki lagi. Sedangkan pada siklus II penilaian yang diberikan oleh observer I terhadap perencanaan yang telah dilakukan adalah kesesuaian antara indikator dengan standar kompetensi dan kompetensi dasar nya sudah sesuai, kemudian pemilihan materi ajar 
telah sesuai dengan tujuan pembelajaran, pemilihan materi ajar telah sesuai dengan karakteristik peserta didik, serta kesesuaian antara pemilihan materi ajar dengan alokasi waktu juga sudah sesuai.

Skenario pembelajaran telah sesuai dengan metode yang digunakan yaitu model kooperatif learnig start with a question. Berdasarkan penilaian tersebut dapat disimpulkan bahwa perencanaan yang dilakukan oleh peneliti pada siklus II ini sudah jauh lebih baik daripada siklus sebelumnya.

\section{Proses Pembelajaran Bahasa Indonesia pada} Materi Membaca Selalu Hemat Energi dengan Menggunakan Model Kooperatif Learnig Start With A Question

Berdasarkan hasil pelaksanaan pada siklus I, pembelajaran masih belum maksimal, masih banyak terdapat siswa yang belum tuntas pada indikator penggunaan tanda baca. Ini dikarenakan kurangnya pengawasan guru terhadap siswa ketika siswa sedang mengerjakan tugas menulis karangan, siswa tergesa-gesa membuat karangan narasi karena penggunaan waktu yang tidak maksimal dan ketika berkelompok sebagian siswa cenderung bercerita dan meribut daripada mengerjakan tugas karangan yang diberikan. Kemudian penyebab lainnya adalah siswa masih bersifat pasif ketika pembelajaran berlangsung, maksudnya siswa masih belum berani mengemukakan pendapatnya ketika guru memberikan pertanyaan seputar materi yang diajarkan.
Keterampilan menulis siswa masih rendah ketika menuangkan ide, dan juga ketika menulis karangan narasi juga masih belum sesuai dengan aspek-aspek dalam penilaian kemampuan membaca. Dalam hal ini, guru perlu melakukan bimbingan yang lebih terhadap siswa, agar siswa merasa nyaman sehingga berani menyampaikan ide dan pendapatnya terkait pembelajaran.

Pada siklus II ini sudah berjalan lebih baik daripada siklus sebelumnya. Hal ini ditandai dengan siswa sudah lebih memperhatikan guru ketika guru menyampaikan materi pelajaran, siswa juga sudah lebih aktif dalam proses pembelajaran dan berani mengemukakan pendapatnya atau menjawab pertanyaan yang diberikan oleh gurunya. Pada siklus II ini siswa juga sudah mampu dalam mengerjakan tugas pada pelajaran Bahasa Indonesia pada materi membaca selalu hemat energi sudah mengalami peningkatan.

Berdasarkan hasil pelaksanaan pada siklus I hingga siklus II ini, kemampuan membaca siswa pada pembelajaran Bahasa Indonesia materi membaca selalu hemat energi dengan menggunakan model kooperatif learnig start with a question mengalami peningkatan pada siswa kelas IV SD PT. Tunggal Yunus Pertapahan.

3. Peningkatan Kemampuan Membaca Selalu Hemat Energi pada Tema 2 Siswa Dengan Menggunakan Model Kooperatif Learnig Start With A Question 
Berdasarkan dari data sebelum diterapkannya model kooperatif learnig start with a question, diketahui bahwa hasil belajar siswa terhadap pelajaran Bahasa Indonesia pada materi menulis karangan narasi masih kurang, yaitu dengan rata-rata 73,6 , sedangkan ketuntasan klasikalnya yaitu 35\%. Hal ini disebabkan karena selama ini guru masih menggunakan metode lama, dan pembelajaran hanya terfokus pada guru sedangkan siswa hanya mencatat pada buku catatan, sehingga siswa menjadi merasa bosan.

Hasil keterampilan menulis karangan siswa pada siklus I mengalami peningkatan dari sebelumnya yaitu dari 63,6 menjadi 73,95. Pada siklus ke II, rata-rata hasil belajar siswa adalah 82,7. Dari 25 orang, sebanyak 20 orang telah mencapai ketuntasan secara individual, sedangkan ketuntasan siswa secara klasikal telah mencapai $95 \%$ atau hanya 5 orang saja yang tidak tuntas. Secara klasikal, hasil belajar siswa telah mencapai kriteria yang telah ditetapkan. Berdasarkan ketuntasan klasikal di atas, dapat disimpulkan bahwa nama siswa yang tidak tuntas pada siklus II ini sama dengan nama siswa yang tidak tuntas pada siklus pertama, yaitu SP dengan nilai pada siklus I adalah 77, dan nilai pada siklus ke II adalah 673. Kemudian ada DP dengan nilai pada siklus I adalah 83, dan nilai pada siklus II adalah 83.Ketiga ada PR dengan nilai pada siklus I adalah 70 dan pada siklus kedua adalah 70 .

Penyebab siswa tersebut tidak tuntas adalah karena pada saat pembelajaran berlangsung mereka asyik bermain dibangku mereka yang jaraknya berdekatan, kemudian kepercayaan diri siswa tersebut juga rendah, mereka tidak mau ketika diminta oleh guru untuk menyampaikan pendapat.Selain itu, penyebab hasil belajar siswa dapat dipengaruhi oleh beberapa faktor. Hal ini juga di ungkapkan oleh (Daryanto, 2009) bahwa hasil belajar siswa dipengaruhi oleh faktor internal dan eksternal, yaitu:

Faktor internal:

a) Faktor jasmaniah, meliputi: faktor kesehatan dan cacat tubuh.

b) Faktor psikologis, meliputi: intelegensi, perhatian, minat, bakat, motif, kematangan, dan kesiapan.

c) Faktor kelelahan

Faktor eksternal:

a) Faktor keluarga meliputi: cara orang tua mendidik, relasi antara anggota keluarga, suasana rumah, keadaan ekonomi keluarga, pengertian orang tua, dan latar belakang kebudayaan.

b) Faktor Sekolah meliputi: metode mengajar, kurikulum, hubungan guru dan siswa, hubungan siswa dan siswa, disiplin sekolah, alat pelajaran, waktu sekolah, Standar pelajaran di atas ukuran, keadaan gedung, metode belajar, dan tugas rumah.

Dalam meningkatkan kemampuan membaca selalu hemat energi pada tema 2 siswa, pemilihan model pembelajaran yang tepat sangat berpengaruh terhadap hasil belajar siswa.Salah satu pemilihan model yang tepat untuk pembelajaran Bahasa Indonesia 
416 Penerapan Model Kooperatif Tipe Learnig Start With A Question untuk Meningkatkan Kemampuan Membaca di Sekolah Dasar - Yanti Yandri Kusuma

DOI: https://doi.org/10.31004/basicedu.v5i1.723

berdasarkan hasil tindakan yang telah dilakukan, model kooperatif learnig start with a question memberikan dampak positif terhadap siswa bahwa kemampuan membaca selalu hemat energi pada tema 2 kelas IV Sekolah Dasar.

Berdasarkan hasil penelitian ini membuktikan bahwa hipotesis jika model kooperatif learnig start with a question diterapkan, maka kemampuan membaca selalu hemat energi pada tema 2 kelas IV Sekolah Dasar PT.Tunggal Yunus Pertapahan.

\section{SIMPULAN}

Berdasarkan hasil analisis data, proses dan hasil Kemampuan membaca Selalu hemat energi Pada Tema 2 di kelas IV SD dengan menggunakan model learnig start with a question pada siklus I dan siklus II telah mencapai sasaran yaitu adanya peningkatan Kemampuan membaca Selalu hemat energi Pada Tema 2 di kelas IV SD PT. Tunggal Yunus, rata-rata siswa pada pratindakan adalah 73,6 dengan kategori kurang (60\%-69\%). Pada siklus I pertemuan 1 sebesar 76 dengan kategori kurang (60\%-69\%) dan meningkat pada pertemuan 2 sebesar 81,85 dengan kategori cukup (70\%79\%). Kemudian pada siklus II pertemian 1 mengalami peningkatan menjadi 85,35 dengan kategori cukup (70\%-79\%). Lalu meningkat lagi pada pertemuan 2 menjadi 84,8 dengan kategori baik (80\%-89\%). Sedangkan presentase ketuntasan klasikal keterampilan menulis karangan narasi pratindakan adalah 35\% (5 siswa dari 20 siswa) dengan kategori kurang sekali $(<59 \%)$. Pada siklus I pertemuan 1 sebesar $40 \%$ (6 siswa dari 25 siswa) dengan kategori kurang sekali $(<59 \%)$ dan pertemuan 2 meningkat menjadi 55\% (9 siswa dari 20 siswa) dengan kategori kurang sekali $(<59 \%)$. Pada siklus II pertemuan 1 meningkat menjadi 80\% (14 siswa dari 20 siswa) dengan kategori cukup (70\%-79\%). Kemudian meningkat lagi pada pertemuan 2 sebesar $87 \%$ (20 siswa dari 25 siswa) dengan kategori baik (80\%-89\%).

Berdasarkan hasil penelitian di atas, maka saran peneliti yang berhubungan dengan penelitian ini adalah sebagai berikut:

1. Bagi guru, dalam menerapkan model pembelajaran koperatif learnig start with a question diharapkan membiasakan siswa belajar melalui kegiatan kelompok agar keterampilan menulis karangan narasi siswa meningkat. Guru juga diharapkan untuk memperhitungkan pembagian waktu dengan tepat dan cukup agar siswa memiliki waktu yang cukup untuk menulis karangan narasi.

2. Bagi sekolah, agar dapat meningkatkan keterampilan menulis karangan dan menjadi acuan pembelajaran dengan menggunakan model kooperatif learnig start with a question dan model pembelajaran lainnya seperti gambar dan video dengan memfasilitasi guru agar bisa menambah pengetahuannya dan memotivasi guru untuk bisa meningkatkan keterampilan menulis karangan narasi siswa. Sekolah juga harus mengawasi kegiatan guru di kelas karena tidak semua guru menggunakan jam pembelajaran dengan benar.

Bagi peneliti selanjutnya yang tertarik meneliti keterampilan menulis karangan narasi siswa dengan model pembelajaran kooperatif learnig start with a question sebagai bahan 
417 Penerapan Model Kooperatif Tipe Learnig Start With A Question untuk Meningkatkan Kemampuan Membaca di Sekolah Dasar - Yanti Yandri Kusuma

DOI: https://doi.org/10.31004/basicedu.v5i1.723

penelitiannya harus memahami dengan sungguhsungguh langkah-langkah yang terdapat pada model pembelajaran learnig start with a question agar pembelajaran dapat berjalan sesuai yang diharapkan dan agar menambah observer lebih dari satu orang karena yang diamati itu proses pembelajaran dan data yang diperoleh lebih valid.

\section{DAFTAR PUSTAKA}

Arikunto, S. (2015).Penelitian Tindakan Kelas. Jakarta : PT Bumi Aksara

Doyin dan Wagiran. (2009). Bahasa Indonesia: Pengantar Penulis Karya Ilmiah. Semarang : UNNES PRESS

Daryanto. (2009). Panduan Proses

Ihsan.(2010). Dasar-dasar Kependidikan. Jakarta: Rineka Cipta.

Iskandar.(2009). Penelitian Tindakan Kelas. Jakarta: GP. Press.

Pembelajaran.Jakarta: AV Publisher.

Peraturan Pemerintah Nomor 32 Tahun 2013 Pasal $77 \mathrm{G}$

Peraturan Menteri Pendidikan Nasional Republik Indonesia Nomor 22 Tahun 2006 Tentang Standar Isi Untuk Satuan Pendidikan Dasar Dan Menengah. 2006. Jakarta: Diperbanyak oleh PT Armas Duta Jaya.

Pebriana,

P.H.

(2017).

PeningkatanKeterampilanMenulisPuisiBe bas

MenggunakanPendekatanKontekstualSisw aSekolahDasar. Jurnal Publikasi Pendidikan Volume 7 Nomor 2, Juni 2017.

Purwanto, Ngalim.1997. Metodologi Pengajaran Bahasa Indonesia di Sekolah Dasar. Bandung: Remaja Rosda Karya.

Rahim, Farida. 2007. Pengajaran Membaca di Sekolah Dasar. Jakarta: Bumi Aksara.
Riduan \& Sunarto, (2012).Pengantar Statistika untuk Penelitian Tindakan Pendidikan, Sosial, Ekonomi, Komunikasi Dan Bisnis. Bandung: Alfabeta.

Rohman, Fathur. 2005. Pengembangan Pembelajaran Membaca. Makalah disampaikan dalam bimbingan Teknis Guru Mata Pelajaran Bahasa Indonesia seJawa Tengah, yang diselenggarakan oleh sub Dinas Pengembangan Tenaga Kependidikan dan Non-Kependidikan Seksi PTK

Slamet, St. Y.. 2008. Dasar-Dasar Keterampilan Berbahasa Indonesia. Surakarta: UNS Press

Soyomukti.(2016). Pengantar Ilmu Komunikasi. Yogyakarta: Ar-Ruzz Media

Suyatno.(2009). Menjelajah Pembelajaran Inovatif.Sidoarjo: Masmedia Buana Pustaka.

Tarigan, Henri Guntur. 1989. Membaca Sebagai Suatu Ketrampilan Berbahasa. Bandung :Angkasa.

Tuminto, Didik. 2007. Keterampilan Berbahasa. Jakarta: Rajawali Pres.

Tarmizi.(2013). Peningkatan Menulis Puisi Siswa Dengan Teknik Pemodelan Di Kelas VIIID SMP Negeri 19 Kota Bengkulu.pdf. Universitas Bengkulu. 